\title{
Interleukin-37: A crucial cytokine with multiple roles in disease and potentially clinical therapy (Review)
}

\author{
LIJUAN WANG $^{1,2}$, YANCHUN QUAN ${ }^{1}$, YONGFANG YUE ${ }^{3}$, XUEYUAN HENG ${ }^{4 *}$ and FENGYUAN CHE ${ }^{1 *}$ \\ ${ }^{1}$ Central Laboratory and ${ }^{2}$ Department of Hematology, Hematology Laboratory, Linyi People's Hospital, Shandong University, \\ Linyi, Shandong 276000; ${ }^{3}$ Department of Gynecologic Oncology, Women's Hospital, School of Medicine, Zhejiang University, \\ Hangzhou, Zhejiang 310003; ${ }^{4}$ Department of Neurosurgery, Linyi People's Hospital, Shandong University, \\ Linyi, Shandong 276000, P.R. China
}

Received May 17, 2017; Accepted October 19, 2017

DOI: $10.3892 / \mathrm{ol} .2018 .7982$

\begin{abstract}
Interleukin (IL)-37, a new IL-1 family member, has received increasing attention in recent years. In the past decade,
\end{abstract}

Correspondence to: Dr Fengyuan Che, Central Laboratory, Hematology Laboratory, Linyi People's Hospital, Shandong University, 27 East Jiefang Road, Lanshan, Linyi, Shandong 276000, P.R. China

E-mail: fyche1971@163.com

Dr Xueyuan Heng, Department of Neurosurgery, Linyi People's Hospital, Shandong University, 27 East Jiefang Road, Lanshan, Linyi, Shandong 276000, P.R. China

E-mail: sdxyheng@163.com

${ }^{*}$ Contributed equally

Abbreviations: IL-1, interleukin-1; IL-37, interleukin-37; IL-1F7, IL-1 family member 7; IL-18R, IL-18 receptor; NK, natural killer; TLR, toll-like receptor; IFN, interferon; TGF- $\beta 1$, transforming growth factor $\beta 1$; TNF, tumor necrosis factor; GM-CSF, granulocyte-macrophage colony-stimulating factor; YFP, yellow fluorescence protein; CFP, cyan fluorescence protein; MAPK, mitogen activated protein kinases; JNK, the Jun N-terminal kinase; ERK, extracellular signal-regulated kinase; PI3Ks, Phosphatidylinositol 3-kinases; TwHF, Tripterygium wilfordii Hook F; hBD-3, human $\beta$-defensin-3; DCs, dendritic cells; HCAECs, human coronary artery endothelial cells; MHC, major histocompatibility complex; Tregs, regulatory $\mathrm{T}$ cells; DSS, dextransulfate sodium; UC, ulcerative colitis; CD, Crohn's disease; MC, microscopic colitis; AS, Ankylosing spondylitis; GD, Graves' disease; FT3, free triiodothyronine; FT4, FT4, freethyroxine; TSH, thyrotropin; TRAB, thyrotropin receptor antibody; Lm, Liseria monocytogenes; SLE, systemic lupuserythematosus; IBD, inflammatory bowel disease; AR, allergic rhinitis; AMI, acute myocardial infarction; ASTEMI, acute ST-segment elevation myocardial infarction; HCC, hepatocellular carcinoma; DFS, disease-free survival; OS, overall survival; $\mathrm{CC}$, cervical cancer; STAT3, signal transducer and activator of transcription 3; NSCLC, non-small cell lung cancer; CAD, coronary artery disease

Key words: IL-37, inflammation, expression, regulation, function, clinical application it has been determined that IL-37 is expressed in various normal cells and tissues and is regulated by inflammatory stimuli and pro-cytokines via different signal transduction pathways. Recently, it has been found that IL-37 is expressed in a variety of cancers, chronic inflammatory and autoimmune disorders, and exerts anti-inflammatory effects. Moreover, a growing body of literature demonstrates that IL-37 plays a vital role in inhibiting both innate and adaptive immune responses as well as inflammatory reactions. In addition, IL-37 may prove to be a new and potentially useful target for effective cytokine therapy. Further evidence is needed to clarify in more detail the effects of IL-37 in experimental and clinical studies. Based on an extensive summary of published data, the aim of this review is to outline the current knowledge of IL-37, including the location, structure, expression, regulation and function, as well as the potential clinical applications of this cytokine.

\section{Contents}

1. Introduction

2. Location and structure of IL-37

3. Expression and regulation of IL-37

4. The function of IL-37

5. IL-37 expression in human diseases

6. Potential roles of IL-37 in clinical therapy

7. Conclusion

\section{Introduction}

The immune system is a complex, balanced and organic entity. Under normal conditions, cells of the immune system recognize foreign antigens and destroy them, while playing a continuous role in immune regulation, it is vital to maintain a balanced immune response. Cytokines are small secreted proteins which function as the mediators of cell differentiation, specificity, inflammation, immunopathology and immune responses (1-3). The interleukin-1 (IL-1) family cytokines play a central role in mediating the activation of innate and adaptive immune responses (4). So far, eleven IL-1 family members have been identified, including seven receptor agonists (IL-1 $\alpha$, 
IL-1 $\beta$, IL-18, IL-33, IL-36 $\alpha$, IL-36 $\beta$ and IL-36 $\gamma$ ), three ligands with antagonist activity (IL-1Ra, IL-36Ra and IL-38) and a newly renamed anti-inflammatory cytokine, IL-37 (4-6). IL-37, originally known as IL-1 family member 7 (IL-1F7), is the seventh member of the IL-1 family discovered by computational cloning in 2000 and was renamed in 2010 (7-9). IL-37 has been investigated as a natural inhibitor of immune responses in chronic inflammatory and autoimmune disorders and cancer. In this review, we will summarize the current knowledge of the location, structure, expression and regulation of IL-37. Furthermore, we will discuss the function and potential clinical application of IL-37 for identifying novel therapeutic targets and developing new IL-37-based therapies for the treatment of human diseases.

\section{Location and structure of IL-37}

The human IL-37 gene cluster is located on chromosome $2(9,10)$. The IL-37 gene seems to be absent in mice as no cDNA or genomic sequence related to human IL-37 has been reported $(9,11)$. The IL-37 gene size is $3.617 \mathrm{~kb}$ and includes six exons which encode a $17-26 \mathrm{KDa}$ protein $(9,12)$. The IL-37 gene undergoes alternative splicing; five different splice variants of IL-37 have been identified and termed IL-37a-e, of which IL-37b is the largest (218 amino acids ) and best characterized isoform (Fig. 1) $(8,9,13,14)$. The transcript variant encoded by IL-37b contains exons 1 and 2 and has an $\mathrm{N}$-terminal prodomain, which includes a potential caspase-1 cleavage site, leading to the IL-37b precursor being spliced into mature IL-37b $(9,11)$. In addition, IL-37b also encodes exons 4-6 which contain the 12 putative $\beta$-strands necessary for forming the IL-1-like $\beta$-trefoil secondary structure $(9,15)$. IL-37b shares a $\beta$-barrel structure which is commonly present in other members of the IL-1 family, and binds to the IL-18 receptor (IL-18R) $\alpha$ chain $(16,17)$. IL-37a has a distinctive start codon in exon 3 which encodes a unique $\mathrm{N}$-terminus and is absent in IL-37c, IL-37d and IL-37e, which is then spliced in exons 4 to $6(9,16)$. The sequence encoded by exon 3 results in a prodomain which is processed into the mature form of IL-37a protein (10). IL-37c, first reported by Busfield et al, is similar to IL-37b (18). The IL-37c transcript variant comprises exons 1 and 2 followed by exons 5 and 6 (9). It seems that IL-37c could not represent a functional form a cytokine (9). Exon 2 of IL-37d is missing, instead it contains only exon 1 followed by exons 4-6 and may function as a cytokine (9). IL-37e comprises only exons 1, 5 and 6 and can not bind to IL-18R as a result of lacking exon 4 (9). Interestingly, a chimeric transcript including exons 1, 4 and 5 of IL-37 has been found to be cleaved into the 5'UTR of the full length IL-36 $\gamma$ message $(9,10)$.

\section{Expression and regulation of IL-37}

Expression. IL-37a, IL-37b, and IL-37c are found to be expressed in a variety of normal cells and tissues including natural killer (NK) cells, stimulated B cells, monocytes, skin keratinocytes, epithelial cells, lymphnode, thymus, lung, colon, uterus and bone marrow (9,18-25). However, some IL-37 isoforms are expressed in a tissue specific manner. Brain only expresses IL-37a, kidney only IL-37b, heart only IL-37c, and bone marrow and testis only IL-37d (9,10,26,27). IL-37b was first discovered in bone marrow, and was synthesized by neutrophils (28). Following this, IL-37b has been found mainly in blood cells, skin keratinocytes, and the respiratory and gastrointestinal tracts (28). The chimeric transcript including exons 1, 4 and 5 of IL-37 is also found in testis and placenta, but its function remains unclear (9).

It is estimated that IL-37 protein translocates to the nucleus, redistributes between intracellular and extracellular sites and affects cellular responses, which may explain why the IL-37 level is reduced in serum $(28,29)$. What is noteworthy is that IL-37 expression is seemingly dependent on the inflammatory milieu and inflammatory cells (11). Emerging evidence demonstrates that IL-37 is expressed at low levels in human cells and tissues but upregulated by inflammatory stimuli and pro-cytokines including several toll-like receptor (TLR) agonists, IL-18, interferon (IFN) $\gamma$, IL-1b, transforming growth factor $\beta 1$ and tumor necrosis factor (TNF) (Table I) $(17,30,31)$. Other factors, such as granulocyte-macrophage colony-stimulating factor (GM-CSF) plus IL-4, suppress IL-37 expression (17). Li et al proved that IL-37 is increased after stimulation by TLR agonists in monocytes (28). Interestingly, Nold et al clarified that IL-37b protein expression increased dose-dependently after stimulation with LPS in a mouse macrophage RAW cell line that stably expresses human IL-37b (17).

To further investigate the intracellular expression pattern of IL-37b, Sharma et al generated fusion proteins of IL-37b, with either yellow fluorescence protein (YFP) at the $\mathrm{C}$ terminus (IL-37b-YFP) or cyan fluorescence protein (CFP) at the $\mathrm{N}$ terminus (IL-37b-CFP) by using protein fusing techniques (29). They then transfected mouse RAW cells with these two different IL-37b fusion proteins, intracellular expression of which were found to be at low levels. However, after LPS stimulation, only IL-37b-YFP translocated into the nucleus, which suggests that the $N$ terminus of IL-37b is processed before nuclear translocation (29). Therefore, only the post-cleavage mature form of the IL-37b precursor, but not the $\mathrm{N}$ terminal fragment, specifically translocates to the nucleus after LPS exposure (29). Thus, after stimulation, IL-37 is processed from pro-protein to its mature form (9).

Regulation. The mitogen activated protein kinases (MAPK) signal pathway is one of the main signaling pathways involved in immune responses, with vital roles in the regulation of cytokine and chemokine responses (32). There are three main components in the MAPK signaling pathway: The Jun N-terminal kinase (JNK 1/2/3), extracellular signal-regulated kinase (ERK1/2, ERK 3/4, ERK5, ERK 7/8,) and p38 MAPKs $(\mathrm{p} 38 \alpha / \beta / \gamma / \delta)$ (33-36). Once stimulated, the MAPKs, which are expressed in all cell types, are activated and participate in various physiological and biologic processes including inflammation, growth, differentiation, survival and apoptosis of cells (35-37). Phosphatidylinositol 3-kinases (PI3Ks) are a family of lipid kinases that play important roles in intracellular signal transduction and regulation of inflammatory and immune processes $(38,39)$. Based on protein structure and substrate specificity, PI3Ks are classified into three classes, PI3K I-III (39).

Recent studies have identified MAPK and PI3K signaling pathways as mediators of regulating various agents in IL-37 expression. Triptolide and triptonide, two 
Table I. Factors and signal pathways involved in IL-37 expression.

\begin{tabular}{llll}
\hline Cell type & \multicolumn{1}{c}{ Triggering factor } & Regulation & \multicolumn{1}{c}{ Signal pathway involved } \\
\hline Monocytes & TLR agonists & Increased & Unclear \\
RAW cell line & LPS & Increased & Unclear \\
THP cells & Triptolide, triptonide & Increased & ERK1/2, p38 \\
Human cells & TNF-a & Increased & MAPK, PI3K, NF-kB, AP-1 \\
Epithelial cells & Mannose-capped lipoarabinomannan & Increased & ERK1/2, p38 \\
Keratinocytes & Human $\beta-$ defensin-3 & Increased & CCR6 \\
Human cells & IL-18, IFN- $\gamma$, IL-1b, TGF- $\beta 1$ & Increased & Unclear \\
Human cells & GM-CSF, IL-4 & Iecreased & Unclear \\
Endothelial cells & ICAM-1, NF- $\mathrm{KB}$ & Iecreased & TLR2 activation \\
BMDMs & M-CSF, GM-CSF, IL-6 & Iecreased & Unclear \\
HUVECs & VEGF & Iecreased & Unclear \\
\end{tabular}

BMDM, bone marrow-derived macrophages; HUVECs, human umbilical vein epithelial cells; IL, interleukin; TLR, toll-like receptors; LPS, lipopolysaccharide; TNF-a, tumor necrosis factor $\alpha$; IFN, interferon; TGF- $\beta 1$, transforming growth factor $\beta 1$; GM-CSF, granulocyte macrophage-colony stimulating factor; NF- $\mathrm{KB}$, nuclear factor $\mathrm{\kappa B}$; ICAM-1, intercellular adhesion molecule 1; M-CSF, macrophage colony stimulating factor; VEGF, vascular endothelial growth factor; ERK1/2, extracellular signal-related kinase; MAPK, mitogen activated protein kinase; PI3K, phosphoinositide 3-kinase; AP-1; activator protein 1; p38, tumor protein 38 .

\begin{tabular}{|l|l|l|l|l}
\hline E3 & E4 & E5 & E6 & IL-37a \\
\hline
\end{tabular}

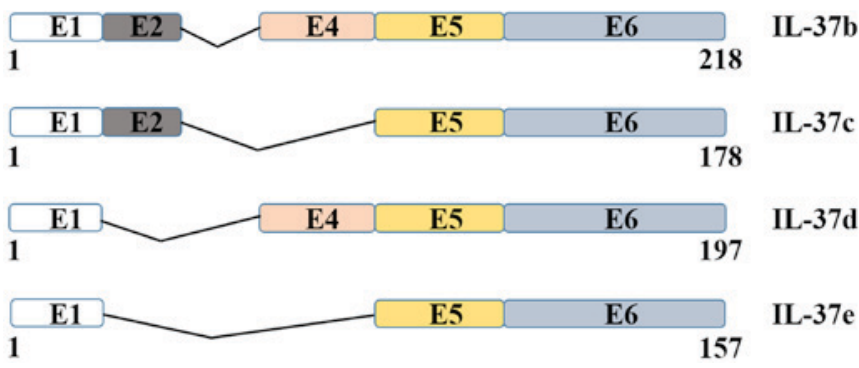

Figure 1. Variants of IL-37. The five splice variants transcripts of the IL-37 gene are shown. Exons 5 and 6 are shared with all five isoforms. Exon 1 is absent in IL-37a only. IL-37c shares with IL-37b exons 1,2, 5 and 6. IL-37d is similar to IL-37b, sharing exons 1, 4, 5 and 6. E, exon; IL, interleukin.

active components extracted from the herb Tripterygium wilfordii Hook F (TwHF), upregulate IL-37 expression and this expression is suppressed by inhibitors of the ERK1/2 and p38 signal pathways in THP cells (30). TNF- $\alpha$ induces IL-37b mRNA expression by activating MAPK and PI3K signaling pathways and the transcription factors $N F-\kappa B$ and AP-1 (28). Mannose-capped lipoarabinomannan purified from Mycobacterium tuberculosis induces IL-37 production in a time- and dose-dependent manner via upregulating TLR2 expression and enhancing $\mathrm{p} 38$ and ERK1/2 phosphorylation in human type II alveolar epithelial cells (40).

A study in human PBMCs has shown that $I L-I F 7$ expression is markedly increased by activation of each TLR, except TLR7 and TLR8 (41). Optimization of the TLR5 response causes a significant increase in IL-37 mRNA and protein expression in intestinal epithelial cells (42). In a recent study, it has been demonstrated that human $\beta$-defensin-3 (hBD-3) upregulates IL-37 expression via CCR6 in human keratinocytes (43). In addition, hBD-3 also induces the release of IL-37 into the culture supernatants. However, the signaling pathways participating in IL-37 expression remain to be defined, and the mechanisms of IL-37 regulation will continue to attract further attention.

\section{The function of IL-37}

The biological function of IL-37 is just beginning to be explored (Fig. 2) (26). There is still a long way to go before the specific role of IL-37 is completely elucidated, but so far, the anti-inflammatory effect of IL-37 has been comprehensively reported. As an inhibitor of both innate and adaptive immunity and inflammatory responses, IL-37 plays a pivotal role in the antimicrobial response, including antiviral, antibacterial, neutralization of endotoxins and anti-immune and tumor regulation, mainly by changing the permeability of bacterial cells (28).

IL-37 significantly decreases proinflammatory cytokines secreted by macrophages and dendritic cells (DCs), inhibits their activation and macrophages differentiation (11). SiRNA knockdown of IL-37 in PBMCs and human renal tubular epithelial cells increases the production of IL-6, TNF- $\alpha$ and IL-1 $\beta$ induced by inflammatory stimuli and cytokines (44). In human coronary artery endothelial cells (HCAECs), IL-37 suppresses both NF- $\kappa$ B and ICAM-1 expression upon TLR2 activation (45). Moreover, Li et al demonstrated that epithelial cell-derived IL-37 inhibits T cell and DCs activation in the inflammatory mucosa of inflammatory bowel disease (IBD), possibly by reducing CD86 and major histocompatibility complex (MHC) II surface expression in DCs (28). IL-37 induction of tolerogenic DCs may help to induce regulatory $\mathrm{T}$ cells (Tregs) (11). Nold et al found that IL-37 functions partly via the IL-37-smad3 complex in the nucleus and smad3 knockdown reduces the activity of IL-37 (17). McNamee et al proved that transgenic expression of human IL-37 (IL-37tg) remarkably protects against LPS-induced shock in a mouse model (31). 


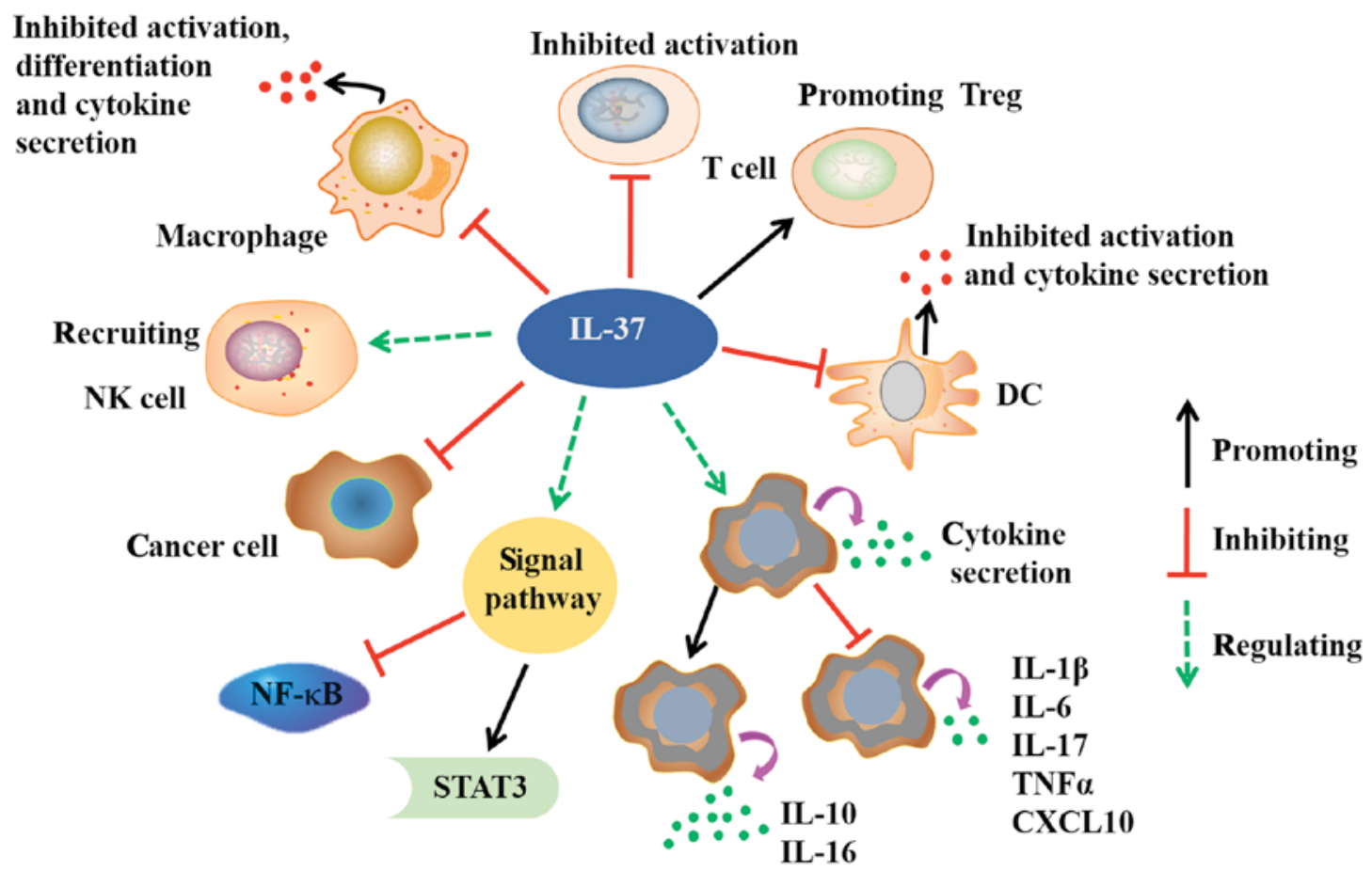

Figure 2. Possible biological functions of IL-37. IL-37 exerts significant anti-inflammatory, anticancer, immune deviatory, immunosuppressive, and metaboregulatory effects. IL-37 dramatically reduces the cytokines secretion in macrophages and DCs. The activation and differentiation of macrophages, DCs and $\mathrm{T}$ cells are also inhibited by IL-37. In addition to healthy tissues, IL-37 is variably expressed in many cancer cells. IL-37 exerts antitumor immune responses through recruiting NK cells into tumors tissues. The binding of IL-37 to its receptor activates STAT-3, and inhibits NF-kB signals. IL, interleukin; STAT-3, signal tranducer and activator of transcription 3; NF-kB, nuclear factor kB; DC, dendritic cell; Treg, T regulatory cell; TNF $\alpha$, tumor necrosis factor $\alpha$; CXCL10, C-X-C motif chemokine 10.

In addition, IL-37tg mice subjected to dextransulfate sodium-induced colitis show a lower level of colonic inflammation, decreased IL- $1 \beta$ and TNF- $\alpha$ secretion, but increased IL-10 production (31). Furthermore, IL-10 is not necessary for IL-37 function as an IL-10 receptor blocking antibody has no effect on IL-37-mediated anti-inflammatory effects (31). rIL-37tg mice also exhibit inhibition of cytokine and chemokine (IL-6, IL-1a, IL-13, GM-CSF, etc) expression after spinal cord injury (46). Therefore, IL-37 plays a vital role in modulation of intestinal and spinal cord inflammation. Besides, IL-37 strongly inhibit TNF- $\alpha$-induced IP-10 expression (47). Except for its anti-inflammatory effects, Zhao et al indicated that IL-37 is also a negative regulator of immune responses in Liseria monocytogenes ( $\mathrm{Lm}$ ) infection due to reduced production of colony-stimulating factors and increased macrophage apoptosis (48).

Similar to IL-33 and IL-1 $\alpha$, IL-37 also translocates into the nucleus in a caspase-1-dependent manner, decreases cytokine production and affects innate and adaptive immune responses $(29,49)$. Li et al reported an extracellular function of the IL-37 precusor, which suppresses LPS-induced IL-6 production in human M1 differentiated macrophages (49). IL-37 acts as an extracellular cytokine by binding to the IL-18 receptor and requires the IL-1 family decoy receptor IL-1R8 for its anti-inflammatory function (49) It has been shown that these pro-inflammatory cytokines (TNF- $\alpha$, IL- $1 \alpha$, IL- $1 \beta$, IFN- $\gamma$ ) could play pivotal roles in experimental autoimmune thyroiditis, multiple sclerosis, insulin-dependent diabetes mellitus or experimental autoimmune diabetogenesis, which may indirect suggest the biological and potentially therapeutic relevance of
IL-37 to these diseases (50-55). However, it remains unknown whether nuclear translocation of IL-37 is the only mechanism that leads to reduction in cytokine expressions. The specific mechanism of IL-37-mediated suppression of the adaptive immunity also remains unclear. Therefore, further studies on IL-37 function are needed.

\section{IL-37 expression in human diseases}

A growing body of literature has demonstrated that IL-37 is expressed and exerts anti-inflammatory effects in a variety of diseases including melanoma, rheumatoid arthritis, morbid obesity, contact hypersensitivity, atopic dermatitis, liver inflammatory injury, systemic lupus erythematosus (SLE) and IBD, among others (Table II) $(13,14,28,56-65)$. In addition, as IL-37 has a strong effect on inhibiting inflammatory responses, many studies have focused on proving an association between IL-37 expression levels and the severity of inflammatory and autoimmune disease $(66,67)$.

Chronic inflammatory and autoimmune disorders. In recent years, it has been reported that IL-37 expression is apparently related to IBDs. The IL-37 expression level is significantly upregulated in macrophages of Crohn's disease (CD) lesions and in the skin lesions of psoriasis patients (9). Increased epithelial IL-37b protein expression has also been identified in the inflamed mucosa of IBD patients (22). Serum IL-37 levels are significantly reduced in ulcerative colitis (UC) and CD patients compared with healthy subjects (28). IL-37 is expressed in intestinal epithelial and inflammatory 
Table II. Expression and clinical significance of IL-37 in human disorders.

\begin{tabular}{|c|c|c|c|c|c|c|c|}
\hline Author & Year & Disease & $\begin{array}{c}\text { No. of } \\
\text { samples }\end{array}$ & Methods & $\begin{array}{l}\text { Expression } \\
\text { level }\end{array}$ & Association & (Refs.) \\
\hline Liu et al & 2014 & $\begin{array}{l}\text { Children with } \\
\text { allergic rhinitis }\end{array}$ & 40 & ELISA & Decreased & $\begin{array}{l}\text { The efficacy } \\
\text { of intranasal } \\
\text { steroid therapy }\end{array}$ & (14) \\
\hline Li et al & 2014 & Graves' disease & 40 & $\begin{array}{l}\text { RT-PCR and } \\
\text { ELISA }\end{array}$ & Increased & $\begin{array}{l}\text { TNF-a, IL-6, } \\
\text { IL-17 and } \\
\text { disease activity }\end{array}$ & (13) \\
\hline Li et al & 2014 & $\begin{array}{l}\text { Inflammatory } \\
\text { bowel disease }\end{array}$ & 27 & ELISA & Decreased & UC activity & (28) \\
\hline Højen et al & 2015 & $\begin{array}{l}\text { Chronic HIV-1- } \\
\text { infected individuals }\end{array}$ & 60 & $\begin{array}{l}\text { Quantitative } \\
\text { RT-PCR }\end{array}$ & Increased & $\begin{array}{l}\text { The size of } \\
\text { the total viral } \\
\text { HIV-1 reservoir }\end{array}$ & $(56)$ \\
\hline Wan et al & 2014 & $\begin{array}{l}\text { Intervertebral disc } \\
\text { degeneration }\end{array}$ & 14 & $\begin{array}{l}\text { RT-PCR and } \\
\text { western blotting }\end{array}$ & Decreased & $\begin{array}{l}\text { Disease } \\
\text { aggravation }\end{array}$ & $(57)$ \\
\hline Günaltay et al & 2014 & $\begin{array}{l}\text { Microscopic and } \\
\text { ulcerative colitis }\end{array}$ & 31 & $\begin{array}{l}\text { Quantitative } \\
\text { RT-PCR }\end{array}$ & Decreased & $\begin{array}{l}\text { Possible } \\
\text { UC remission }\end{array}$ & $(58)$ \\
\hline Chen et al & 2015 & Ankylosing spondylitis & 46 & RT-PCR and ELISA & Increased & Disease activity & $(59)$ \\
\hline Ye et al & 2014 & $\begin{array}{l}\text { Systemic lupus } \\
\text { erythematosus }\end{array}$ & 66 & RT-PCR and ELISA & Increased & Disease activity & $(60)$ \\
\hline Ji et al & 2014 & $\begin{array}{l}\text { Acute coronary } \\
\text { syndrome }\end{array}$ & 257 & ELISA & Increased & The onset of ACS & $(61)$ \\
\hline Wang et al & 2015 & Myocardial infarction & 56 & Immunoblotting & Decreased & $\begin{array}{l}\text { Possible leukocytic } \\
\text { inflammation }\end{array}$ & $(62)$ \\
\hline Yu et al & 2016 & Arterial calcification & 125 & $\begin{array}{l}\text { Immunohistochemistry } \\
\text { and ELISA }\end{array}$ & Increased & $\begin{array}{l}\text { The onset of } \\
\text { arterial calcification }\end{array}$ & (63) \\
\hline Zhao et al & 2014 & $\begin{array}{l}\text { Hepatocellular } \\
\text { carcinoma }\end{array}$ & 163 & $\begin{array}{l}\text { Immunohistochemical } \\
\text { staining }\end{array}$ & Decreased & $\begin{array}{l}\text { Tumor size, } \\
\text { OS, DFS, the } \\
\text { density of } \\
\text { tumor-infiltrating } \\
\text { NK cells }\end{array}$ & (64) \\
\hline Ge et al & 2016 & $\begin{array}{l}\text { Non-small cell } \\
\text { lung cancer }\end{array}$ & 182 & $\begin{array}{l}\text { Immunohistochemical } \\
\text { staining and RT-PCR }\end{array}$ & Decreased & $\begin{array}{l}\text { Tumor } \\
\text { angiogenesis }\end{array}$ & $(65)$ \\
\hline
\end{tabular}

RT-PCR, reverse transcription polymerase chain reaction; OS, overall survival; DFS, disease-free survival; NK cells, natural killer cells; TNF $\alpha$, tumor necrosis factor $\alpha$; IL, interleukin; HIV, human immunodeficiency virus; ACS, acute coronary syndrome; UC, ulcerative colitis.

cells and serum IL-37 levels show an inverse correlation with UC activity (28). Immunohistochemistry and western blot analyses prove that IL-37 protein expression levels are higher in UC and CD patients than in healthy people, and are highest in samples from UC patients compared with that of CD patients (28). Nevertheless, the function of IL-37 is still not completely understood in different inflammatory diseases and the inflammation in microscopic colitis (MC) is more subtle than in UC and CD (58). Günaltay et al further found that UC remission patients demonstrated increased expression levels of IL-37 mRNA, suggesting that IL-37 may be involved in inflammation and therefore contributing to UC remission (56). On the contrary, low IL-37 expression may contribute to the chronicity of colonic inflammation in $\mathrm{MC}$ and UC patients (56).
IL-37 protein is higher in synovial cells of rheumatoid arthritis patients compared with those of healthy donors $(17,28)$. Luo et al proved that IL-37 expression in DCs impairs the activation of effector $\mathrm{T}$-cell responses, induces Tregs and regulates adaptive immunity in contact hypersensitivity (68). Ankylosing spondylitis (AS) is a common chronic, progressive, immune-mediated inflammatory disorder characterized by sacroileitis and axial inflammation (69). Chen et al showed that IL-37 secretion and mRNA levels are significantly higher in PBMCs isolated from AS patients compared with healthy controls (59). IL-37 level is also correlated with the activity of AS, particularly with the primary pro-inflammatory cytokines involved in AS (59). Furthermore, human recombinant IL-37 dramatically impairs LPS-stimulated IL-6, IL-17, IL-23 and TNF- $\alpha$ production in PBMCs from AS patients (59). 
A recent study showed that over-expressed IL-37 mRNA levels in adipose tissue may lead to better insulin sensitivity and protect against insulin resistance in obesity-related inflammation (70). Additionally, a remarkable positive correlation between IL-37 mRNA level and the size of the HIV-1 reservoir has been elucidated (56). LPS exposure increases IL-37 mRNA expression to higher levels in HIV-1-infected patients compared with non-infected individuals (56). Previously it has been reported that the monocyte inflammatory marker sCD14 is associated with increased mortality in HIV-1 infection, and high levels of sCD163 were observed among HIV-1-infected patients $(71,72)$. However, recently a positive correlation between sCD14 and IL-37 mRNA, rather than SCD163, has been observed in a cross-sectional cohort study, which implies a functional link between IL-37 and monocyte activation (65).

Li et al verified that the levels of IL-37 in PBMCs and serum are remarkably increased in patients with Graves' disease (GD) (13). Higher IL-37 mRNA and serum protein levels are positively correlated with the activity of GD (13). Moreover, serum IL-37 is positively associated with free triiodothyronine (FT3) and free thyroxine (FT4) but negatively correlated with thyrotropin (TSH) (13). Serum IL-37 is also significantly associated with TSH receptor antibody (TRAB), IL-6, IL-17 and TNF- $\alpha$ (13). Surprisingly, IL-37 inhibits the production of TNF- $\alpha$, IL- 6 and IL-17 in PBMCs of GD patients during GD pathogenesis (13). Wan et al reported that decreased IL-37 expression leads to the increased secretion of pro-inflammatory cytokines including IL-16 and IL-1 $\beta$ in degenerative intervertebraldisc, which suggests a function for IL-37 in delaying the progression of intervertebral disc degeneration (57). It has also been shown that IL-37 expression is significantly higher in the plasma of patients with SLE and that IL-37 suppresses the secretion of pro-inflammatory cytokines in PBMCs of SLE patients $(60,73,74)$. IL-37b expression levels in serum and nasal lavage are significantly increased in children with allergic rhinitis (AR) (14). Furthermore, IL-37b decreased Th2 cytokine secreted by PBMCs via MAPK and PI3K signal pathways (14). Conversely, Imaeda et al found that IL-37b suppresses the Th1-chemokine, CXCL10, which implies a possible function of IL-37b in inhibiting Th1 inflammation (22).

In conclusion, these results suggest complicated biological functions of IL-37 in different diseases. IL-37 expression in autoimmune diseases seems to decrease excessive inflammatory immune responses. However, further detailed study remains necessary to explore the specific mechanisms and potential immunosuppressive functions of IL-37 in inflammatory and autoimmune diseases.

Cardiac diseases. IL-37 expression is found to be increased in patients with acute coronary syndrome $(61,75,76)$. Inflammationis an important step and the NF- $\kappa \mathrm{B}$ signaling pathway is activated after acute myocardial infarction (AMI). Moreover, inhibition of the NF- $\mathrm{KB}$ signaling pathway improves cardiac function after AMI through decreasing the left ventricular shortening fraction (77-79). IL-37 expression level is normally low in PBMCs, being mainly expressed in DCs and monocytes, but rapidly increases in the context of inflammation following AMI (61). Plasma IL-37 expression is decreased in patients with acute ST-segment elevation myocardial infarction (ASTEMI) (62). In patients with arterial calcification, high concentrations of IL-37 have been detected and IL-37 is positively correlated with age, fasting glucose, alkaline phosphatase, IL-6, TNF- $\alpha$, C-reactive protein and Agatston scores (63).

Excessive myocardial inflammatory responses to endotoxemia frequently leads to cardiac dysfunction. Expression of IL-37 suppresses LPS-induced MCP-1 and ICAM-1 production and NF- $\kappa \mathrm{B}$ activation in cardiac microvascular endothelial cells (80). In addition, Xu et al found that IL-37 suppresses MPO expression and recombinant IL-37 effectively suppresses activation of the NF- $\mathrm{kB}$ signaling pathway, and finally results in an anti-inflammatory effect in AMI mice (77).

Cancer. Transcripts of IL-37 have been detected in human cancers and human cancer cell lines including THP-1, U937 and A431 $(30,64)$. However, the biological role of IL-37 in cancers and the relationship between this cytokine and cancer is largely unknown.

To explore IL-37 expression, Zhao et al examined a relatively large series of hepatocellular carcinoma (HCC) clinical specimens by immunohistochemistry (64). IL-37 is decreased in tumor tissues compared with adjacent non-tumor tissues and normal liver samples (64). The expression level of IL-37 is negatively correlated with tumor size and high IL-37 expression is linked to disease-free survival (DFS) and better overall survival (OS) in HCC patients, which suggests that IL-37 may be a potentially valuable prognostic marker for HCC patients (64). Wang et al offered evidence that IL-37 inhibits the proliferation and invasion of cervical cancer (CC) cells via the signal transducer and activator of transcription 3 (STAT3) signaling pathway (12). IL-37 upregulated STAT3 expression at the gene and protein levels and reduced STAT3 phosphorylation (12). After transfection with siSTAT3, CC cell proliferation and invasion inhibited by IL-37 was significantly reversed. STAT3 overexpression restored the CC cell growth and invasion, and increased the transcription of TNF- $\alpha$ and IL-1 $\beta$ (12).

IL-37 expression is upregulated in breast carcinoma tissues, which indicates that this cytokine may have a role in tumor progression $(9,81)$. However, IL-37 expression is downregulated in lung cancer tissues and, it suppresses tumorigenesis in non-small cell lung cancer (NSCLC) in vivo. IL-37 may thus have an inhibitory function in NSCLC development $(65,82)$. However, the specific mechanism and signaling pathways involved in the IL-37-induced immune responses in cancer remain unclear and need further exploration. Infiltration of NK cells into the tumor area is necessary for the activation of potent antitumor immunity (83). IL-37 expression in HCC is positively linked to the density of CD57-positive NK cells, and consequently IL-37-overexpressing HCC cells significantly inhibit tumor growth and recruit more NK cells into tumor tissues in vivo mice experiments (64). Thus, IL-37 may be involved in antitumor immune responses via regulating NK cells in the tumor microenvironment.

\section{Potential roles of IL-37 in clinical therapy}

A comprehensive knowledge of the function of cytokines in the pathogenesis of human disorders has led to the exploration of new therapies targeted at neutralizing specific cytokines or 
inhibiting their signaling pathways $(3,84-87)$. IL-37 plays a vital role in innate and adaptive immunity and may be a useful molecule for effective cytokine therapy.

It has been shown that IL-37 suppresses the innate immunity to infection-mediated inflammation, which may be of therapeutic value in reducing pulmonary damage in bacterial diseases (8). Zhao et al and Gao et alfound that intra-tumoral injection of IL-37 leads to strong inhibition of tumor growth and this effect is dependent on T cells and B cells as it is reversed in IL-12-, IFN- $\gamma$ - or Fas ligand-deficient mice and in nude and SCID mice $(64,88)$. Yin et al showed that a single nucleotide polymorphism in the $I L-37$ gene (rs3811047) is significantly associated with coronary artery disease (CAD), which suggests that IL37 represents a new susceptibility gene for CAD (89). However, there have been no clinical trials to date to prove the effect of IL-37 on disease treatment. Therefore, it is of great significance to evaluate whether IL-37 can be implicated in cytokine therapy for curing diseases in the future.

\section{Conclusion}

In summary, as a new anti-inflammatory inhibitor, IL-37 plays important roles in immune responses, protects from inflammatory and autoimmune diseases, and holds great potential for clinical applications. As such, IL-37 research continues to receive increasing attention. However, several IL-37 mysteries remain unclear, and further detailed study remains necessary to fully determine the possible functions of IL-37. While challenges and opportunities still coexist for IL-37, this cytokine may emerge as a new target for diagnosis and therapy of cancer, inflammatory and autoimmune diseases in the near future.

\section{Acknowledgements}

The present study is supported by Funds for the Natural Science Foundation of Shandong Province (grant no. ZR2014HM077), the Key Research Project program of Shandong Province (grant no. 2016GSF201056), Young Scholars of National Natural Science Foundation of China (no. 81402353) and the Medical Health Science and Technology Development Plan of Shandong Province (no. 2014WS0287), China Postdoctoral Science Foundation (no. 2015M580594) and Postdoctoral Innovation Foundation of Shandong Province (grant no. 201502008).

\section{References}

1. Moran EM and Mastaglia FL: Cytokines in immune-mediated inflammatory myopathies: Cellular sources, multiple actions and therapeutic implications. Clin Exp Immunol 178: 405-415, 2014

2. Hoeppli RE, Wu D, Cook L and Levings MK: The environment of regulatory $\mathrm{T}$ cell biology: Cytokines, metabolites and the microbiome. Front Immunol 6: 61, 2015.

3. Venkatesha SH, Dudics S, Acharya B and Moudgil KD: Cytokine-modulating strategies and newer cytokine targets for arthritis therapy. Int J Mol Sci 16: 887-906, 2014.

4. Garlanda C, Dinarello CA and Mantovani A: The interleukin-1 family: Back to the future. Immunity 39: 1003-1018, 2013.

5. Dinarello CA: Interleukin-1 in the pathogenesis and treatment of inflammatory diseases. Blood 117: 3720-3732, 2011.
6. Smith DE: The biological paths of IL-1 family members IL-18 and IL-33. J Leukoc Biol 89: 383-392, 2011.

7. Dinarello C, Arend W, Sims J, Smith D, Blumberg H, O'Neill L, Goldbach-Mansky R, Pizarro T, Hoffman H, Bufler P, et al: IL-1 family nomenclature. Nat Immunol 11: 973, 2010.

8. Moretti S, Bozza S, Oikonomou V, Renga G, Casagrande A, Iannitti RG, Puccetti M, Garlanda C, Kim S, Li S, et al: IL-37 inhibits inflammasome activation and disease severity in murine aspergillosis. PLoS Pathog 10: e1004462, 2014.

9. Boraschi D, Lucchesi D, Hainzl S, Leitner M, Maier E, Mangelberger D, Oostingh GJ, Pfaller T, Pixner C, Posselt G, et al: IL-37: A new anti-inflammatory cytokine of the IL-1 family. Eur Cytokine Netw 22: 127-147, 2011.

10. Taylor SL, Renshaw BR, Garka KE, Smith DE and Sims JE: Genomic organization of the interleukin-1 locus. Genomics 79: 726-733, 2002.

11. Ye L and Huang Z: IL-37 restrains autoimmune diseases. Oncotarget 6: 21775-21776, 2015

12. Wang S, An W, Yao Y, Chen R, Zheng X, Yang W, Zhao Y, $\mathrm{Hu}$ X, Jiang E, Bie Y, et al: Interleukin 37 expression inhibits STAT3 to Suppress the proliferation and invasion of human cervical cancer cells. J Cancer 6: 962-969, 2015.

13. Li Y, Wang Z, Yu T, Chen B, Zhang J, Huang K and Huang Z: Increased expression of IL-37 in patients with Graves' disease and its contribution to suppression of proinflammatory cytokines production in peripheral blood mononuclear cells. PLoS One 9: e107183, 2014.

14. Liu W, Deng L, Chen Y, Sun C, Wang J, Zhou L, Li H and Luo R: Anti-inflammatory effect of IL-37b in children with allergic rhinitis. Mediators Inflamm 2014: 746846, 2014.

15. Murzin AG, Lesk AM and Chothia C: Beta-Trefoil fold. patterns of structure and sequence in the kunitz inhibitors interleukins-1 beta and 1 alpha and fibroblast growth factors. J Mol Biol 223: 531-543, 1992.

16. Banchereau J, Pascual V and O'Garra A: From IL-2 to IL-37: The expanding spectrum of anti-inflammatory cytokines. Nat Immunol 13: 925-931, 2012.

17. Nold MF, Nold-Petry CA, Zepp JA, Palmer BE, Bufler P and Dinarello CA: IL-37 is a fundamental inhibitor of innate immunity. Nat Immunol 11: 1014-1022, 2010.

18. Busfield SJ, Comrack CA, Yu G, Chickering TW, Smutko JS, Zhou H, Leiby KR, Holmgren LM, Gearing DP and Pan Y: Identification and gene organization of three novel members of the IL-1 family on human chromosome 2. Genomics 66: 213-216, 2000

19. Smith DE, Renshaw BR, Ketchem RR, Kubin M, Garka KE and Sims JE: Four new members expand the interleukin-1 superfamily. J Biol Chem 275: 1169-1175, 2000.

20. Ross R, Grimmel J, Goedicke S, Möbus AM, Bulau AM, Bufler P, Ali S and Martin MU: Analysis of nuclear localization of interleukin-1 family cytokines by flow cytometry. J Immunol Methods 387: 219-227, 2013.

21. Akdis M, Burgler S, Crameri R, Eiwegger T, Fujita H, Gomez E, Klunker S, Meyer N, O'Mahony L, Palomares O, et al: Interleukins, from 1 to 37 and interferon- $\gamma$ : Receptors, functions and roles in diseases. J Allergy Clin Immunol 127: 701-721, 2011

22. Imaeda H, Takahashi K, Fujimoto T, Kasumi E, Ban H, Bamba S, Sonoda H, Shimizu T, Fujiyama Y and Andoh A: Epithelial expression of interleukin-37b in inflammatory bowel disease. Clin Exp Immunol 172: 410-416, 2013.

23. Pan G, Risser P, Mao W, Baldwin DT, Zhong AW, Filvaroff E, Yansura D, Lewis L, Eigenbrot C, Henzel WJ and Vandlen R: IL-1H, an interleukin 1-related protein that binds IL-18 receptor/IL-1Rrp. Cytokine 13: 1-7, 2001.

24. Bufler P, Gamboni-Robertson F, Azam T, Kim SH and Dinarello CA: Interleukin-1 homologues IL-1F7b and IL-18 contain functional mRNA instability elements within the coding region responsive to lipopolysaccharide. Biochem J 381: 503-510, 2004

25. Kumar S, McDonnell PC, Lehr R, Tierney L, Tzimas MN, Griswold DE, Capper EA, Tal-Singer R, Wells GI, Doyle ML and Young PR: Identification and initial characterization of four novel members of the interleukin-1 family. J Biol Chem 275: 10308-10314, 2000.

26. Dunn E, Sims JE, Nicklin MJ and O'Neill LA: Annotating genes with potential roles in the immune system: Six new members of the IL-1 family. Trends Immunol 22: 533-536, 2001. 
27. Bufler P, Azam T, Gamboni-Robertson F, Reznikov LL, Kumar S, Dinarello CA and Kim SH: A complex of the IL-1 homologue IL-1F7b and IL-18-binding protein reduces IL-18 activity. Proc Natl Acad Sci USA 99: 13723-13728, 2002

28. Li Y, Wang Y, Liu Y, Wang Y, Zuo X, Li Y and Lu X: The possible role of the novel cytokines il-35 and il-37 in inflammatory bowel disease. Mediators Inflamm 2014: 136329, 2014.

29. Sharma S, Kulk N, Nold MF, Gräf R, Kim SH, Reinhardt D, Dinarello CA and Bufler P: The IL-1 family member 7b translocates to the nucleus and down-regulates proinflammatory cytokines. J Immunol 180: 5477-5482, 2008

30. He L, Liang Z, Zhao F, Peng L and Chen Z: Modulation of IL-37 expression by triptolide and triptonide in THP-1 cells. Cell Mol Immunol 12: 515-518, 2015.

31. McNamee EN, Masterson JC, Jedlicka P, McManus M, Grenz A, Collins CB, Nold MF, Nold-Petry C, Bufler P, Dinarello CA and Rivera-Nieves J: Interleukin 37 expression protects mice from colitis. Proc Natl Acad Sci USA 108 16711-16716, 2011.

32. Su S, Duan J, Chen T, Huang X, Shang E, Yu L, Wei K, Zhu Y, Guo J, Guo S, et al: Frankincense and myrrh suppress inflammation via regulation of the metabolic profiling and the MAPK signaling pathway. Sci Rep 5: 13668, 2015.

33. Guo C, Xia Y, Niu P, Jiang L, Duan J, Yu Y, Zhou X, Li Y and Sun Z: Silica nanoparticles induce oxidative stress, inflammation and endothelial dysfunction in vitro via activation of the MAPK/Nrf2 pathway and nuclear factor $-\kappa B$ signaling. Int $J$ Nanomedicine 10: 1463-1477, 2015.

34. Fang HU Zhang HH, Yang BX, Huang JL, Shun JL, Kong FJ, Peng-Xu, Chen ZG and Lu JM: Cdk5 contributes to inflammation-induced thermal hyperalgesia mediated by the p38 MAPK pathway in microglia. Brain Res 1619: 166-175, 2015.

35. Lei YY, Wang WJ, Mei JH and Wang CL: Mitogen-activated protein kinase signal transduction in solid tumors. Asian Pac J Cancer Prev 15: 8539-8548, 2014.

36. Grossi V, Peserico A, Tezil T and Simone C: p38 $\alpha$ MAPK pathway: A key factor in colorectal cancer therapy and chemoresistance. World J Gastroenterol 20: 9744-9758, 2014.

37. Jha SK, Jha NK, Kar R, Ambasta RK and Kumar P: p38 MAPK and PI3K/AKT signalling cascades inparkinson's disease. Int J Mol Cell Med 4: 67-86, 2015.

38. Lupia E, Pigozzi L, Goffi A, Hirsch E and Montrucchio G: Role of phosphoinositide 3-kinase in the pathogenesis of acute pancreatitis. World J Gastroenterol 20: 15190-15199, 2014.

39. Yip PY: Phosphatidylinositol 3-kinase-AKT-mammalian target of rapamycin (PI3K-Akt-mTOR) signaling pathway in non-small cell lung cancer. Transl Lung Cancer Res 4: 165-176, 2015.

40. Huang Z, Zhao GW, Gao CH, Chi XW, Zeng T, Hu YW, Zheng $L$ and Wang Q: Mannose-capped lipoarabinomannan from mycobacterium tuberculosis induces Il-37 production via upregulating ERK1/2 and p38 in human type II alveolar epithelial cells. Int J Clin Exp Med 8: 7279-7287, 2015.

41. Rudloff I, Cho SX, Lao JC, Ngo D, McKenzie M, Nold-Petry CA and Nold MF: Monocytes and dendritic cells are the primary sources of interleukin 37 in human immune cells. J Leukoc Bio 101: 901-911, 2016

42. Gunaltay S, Ghiboub M, Hultgren $\mathrm{O}$ and Hörnquist EH: Reduced IL-37 production increases spontaneous chemokine expressions in colon epithelial cells. Dig Dis Sci 62 1204-1215, 2017.

43. Smithrithee R, Niyonsaba F, Kiatsurayanon C, Ushio $H$, Ikeda $\mathrm{S}$, Okumura $\mathrm{K}$ and Ogawa $\mathrm{H}$ : Human $\beta$-defensin-3 increases the expression of interleukin-37 through CCR6 in human keratinocytes. J Dermatol Sci 77: 46-53, 2015.

44. Yang Y, Zhang ZX, Lian D, Haig A, Bhattacharjee RN and Jevnikar AM: IL-37 inhibits IL-18-induced tubular epithelial cell expression of pro-inflammatory cytokines and renal ischemia-reperfusion injury. Kidney Int 87: 396-408, 2015.

45. Xie Y, Li Y, Cai X, Wang X and Li J: Interleukin-37 suppresses ICAM-1 expression in parallel with NF- $\kappa \mathrm{B}$ down-regulation following TLR 2 activation of human coronary artery endothelial cells. Int immunopharmacolo 38: 26-30, 2016.

46. Coll-Miró M, Francos-Quijorna I, Santos-Nogueira E, Torres-Espin A, Bufler P, Dinarello CA and López-Vales R: Beneficial effects of IL-37 after spinal cord injury in mice. Proc Natl Acad Sci USA 113: 1411-1416, 2016.

47. Liu M, Guo S, Hibbert JM, Jain V, Singh N, Wilson NO and Stiles JK: CXCL10/IP-10 in infectious diseases pathogenesis and potential therapeutic implications. Cytokine Growth Factor Rev 22: 121-130, 2011.
48. Zhao M, Hu Y, Shou J, Su SB, Yang J and Yang T: IL-37 impairs host resistance to listeria infection by suppressing macrophage function. Biochem Biophys Res Commun 485: 563-568, 2017

49. Li S, Neff CP, Barber K, Hong J, Luo Y, Azam T, Palmer BE, Fujita M, Garlanda C, Mantovani A, et al: Extracellular forms of IL-37 inhibit innate inflammation in vitro and in vivo but require the IL-1 family decoy receptor IL-1R8. Proc Natl Acad Sci USA 112: 2497-2502, 2015.

50. Zaccone P, Fehervari Z, Blanchard L, Nicoletti F, Edwards CK III and Cooke A: Autoimmune thyroid disease induced by thyroglobulin and lipopolysaccharide is inhibited by soluble TNF receptor type I. Eur J Immunol 32: 1021-1028, 2002.

51. Dujmovic I, Mangano K, Pekmezovic T, Quattrocchi C, Mesaros S, Stojsavljevic N, Nicoletti F and Drulovic J: The analysis of IL-1 beta and its naturally occurring inhibitors in multiple sclerosis: The elevation of IL-1 receptor antagonist and IL-1 receptor type II after steroid therapy. J Neuroimmunol 207: 101-106, 2009.

52. Nicoletti F, Patti F, DiMarco R, Zaccone P, Nicoletti A, Meroni P and Reggio A: Circulating serum levels of IL-1ra in patients with relapsing remitting multiple sclerosis are normal during remission phases but significantly increased either during exacerbations or in response to IFN-beta treatment. Cytokine 8: 395-400, 1996.

53. Nicoletti F, Zaccone P, Di Marco R, Lunetta M, Magro G, Grasso S, Meroni P and Garotta G: Prevention of spontaneous autoimmune diabetes in diabetes-prone $\mathrm{BB}$ rats by prophylactic treatment with antirat interferon-gamma antibody. Endocrinology 138: 281-288, 1997.

54. Nicoletti F, Di Marco R, Barcellini W, Magro G, Schorlemmer HU, Kurrle R, Lunetta M, Grasso S, Zaccone P and Meroni P: Protection from experimental autoimmune diabetes in the non-obese diabetic mouse with soluble interleukin-1 receptor. Eur J Immunol 24: 1843-1847, 1994.

55. Akdis M, Aab A, Altunbulakli C, Azkur K, Costa RA, Crameri R, Duan S, Eiwegger T, Eljaszewicz A, Ferstl R, et al: Interleukins (from IL-1 to IL-38), interferons, transforming growth factor $\beta$ and TNF- $\alpha$ : Receptors, functions and roles in diseases. J Allergy Clin Immunol 138: 984-1010, 2016.

56. Højen JF, Rasmussen TA, Andersen KL, Winckelmann AA, Laursen RR, Gunst JD, Møller HJ, Fujita M, Østergaard L, Søgaard OS, et al: Interleukin-37 expression is increased in chronic HIV-1-Infected individuals and is associated with inflammation and the size of the total viral reservoir. Mol Med 21: 337-345, 2015.

57. Wan ZY, Sun Z, Song F, Chen YF, Zhang WL, Wang HQ and Luo ZJ: Downregulated interleukin 37 expression associated with aggravation of intervertebral disc degeneration. Int J Clin Exp Pathol 7: 656-662, 2014.

58. Günaltay S, Nyhlin N, Kumawat AK, Tysk C, Bohr J, Hultgren O and Hultgren Hörnquist E: Differential expression of interleukin-1/Toll-like receptor signaling regulators in microscopic and ulcerative colitis. World J Gastroenterol 20: 12249-12259, 2014.

59. Chen B, Huang K, Ye L, Li Y, Zhang J, Zhang J, Fan X, Liu X, $\mathrm{Li} \mathrm{L}$, Sun J, et al: Interleukin-37 is increased in ankylosing spondylitis patients and associated with disease activity. J Transl Med 13: 36, 2015.

60. Ye L, Ji L, Wen Z, Zhou Y, Hu D, Li Y, Yu T, Chen B, Zhang J, Ding L, et al: IL-37 inhibits the production of inflammatory cytokines in peripheral blood mononuclear cells of patients with systemic lupus erythematosus: Its correlation with disease activity. J Transl Med 12: 69, 2014

61. Ji Q, Zeng Q, Huang Y, Shi Y, Lin Y, Lu Z, Meng K, Wu B, Yu K, Chai M, et al: Elevated plasma IL-37, IL-18 and IL-18BP concentrations in patients with acute coronary syndrome. Mediators Inflamm 2014: 165742, 2014

62. Wang X, Cai X, Chen L, Xu D and Li J: The evaluation of plasma and leukocytic IL-37 expression in early inflammation in patients with acute ST-segment elevation myocardial infarction after PCI. Mediators Inflamm 2015: 626934, 2015.

63. Yu K, Min X, Lin Y, Huang Y, Huang S, Liu L, Peng Y, Meng K, Li D, Ji Q and Zeng Q: Increased IL-37 concentrations in patients with arterial calcification. Clin Chim Acta 461: 19-24, 2016.

64. Zhao JJ, Pan QZ, Pan K, Weng DS, Wang QJ, Li JJ, Lv L, Wang DD, Zheng HX and Jiang SS: Interleukin-37 mediates the antitumor activity in hepatocellular carcinoma: Role for CD57+ NK cells. Sci Rep 4: 5177, 2014. 
65. Ge G, Wang A, Yang J, Chen Y, Yang J, Li Y and Xue Y: Interleukin-37 suppresses tumor growth through inhibition of angiogenesis in non-small cell lung cancer. J Exp Clin Cancer Res 35: 13, 2016.

66. Wu BW, Zeng QT, Meng K and Ji QW: The potential role of IL-37 in atherosclerosis. Pharmazie 68: 857-860, 2013.

67. Sakai N, Van Sweringen HL, Belizaire RM, Quillin RC, Schuster R, Blanchard J, Burns JM, Tevar AD, Edwards MJ and Lentsch AB: Interleukin-37 reduces liver inflammatory injury via effects on hepatocytes and non-parenchymal cells J Gastroenterol Hepatol 27: 1609-1616, 2012.

68. Luo Y, Cai X, Liu S, Wang S, Nold-Petry CA, Nold MF, Bufler P, Norris D, Dinarello CA and Fujita M: Suppression of antigen-specific adaptive immunity by IL-37 via induction of tolerogenic dendritic cells. Proc Natl Acad Sci USA 111: $15178-15183,2014$

69. Jethwa H and Bowness P: The interleukin (IL)-23/IL-17 axis in ankylosing spondylitis: New advances and potentials for treatment. Clin Exp Immunol 138: 30-36, 2016.

70. Ballak DB, van Diepen JA, Moschen AR, Jansen HJ, Hijmans A, Groenhof GJ, Leenders F, Bufler P, Boekschoten MV, Müller M, et al: IL-37 protects against obesity-induced inflammation and insulin resistance. Nat Commun 5: 4711, 2014.

71. Burdo TH, Lentz MR, Autissier P, Krishnan A, Halpern E, Letendre S, Rosenberg ES, Ellis RJ and Williams KC: Soluble CD163 made by monocyte/macrophages is a novel marker of HIV activity in early and chronic infection prior to and after anti-retroviral therapy. J Infect Dis 204: 154-163, 2011.

72. Sandler NG, Wand H, Roque A, Law M, Nason MC, Nixon DE, Pedersen C, Ruxrungtham K, Lewin SR, Emery S, et al: Plasma levels of soluble CD14 independently predict mortality in HIV infection. J Infect Dis 203: 780-790, 2011

73. Wu GC, Li HM, Wang JB, Leng RX, Wang DG and Ye DQ Elevated plasma interleukin-37 levels in systemic lupus erythematosus patients. Lupus 25: 1377-1380, 2016.

74. Song L, Qiu F, Fan Y, Ding F, Liu H, Shu Q, Liu W and Li X: Glucocorticoid regulates interleukin-37 in systemic lupus erythematosus. J Clin Immunol 33: 111-117, 2013.

75. Yang T, Fang F, Chen Y, Ma J, Xiao Z, Zou S, Zheng N, Yan D, Liao S, Chen S, et al: Elevated plasma interleukin-37 playing an important role in acute coronary syndrome through suppression of ROCK activation. Oncotarget 8: 9686-9695, 2017.

76. Liu K, Tang Q, Zhu X and Yang X: IL-37 increased in patients with acute coronary syndrome and associated with a worse clinical outcome after ST-segment elevation acute myocardial infarction. Clin Chim Acta 468: 140-144, 2017.
77. Xu D, Wang A, Jiang F, Hu J and Zhang X: Effects of interleukin-37 on cardiac function after myocardial infarction in mice. Int J Clin Exp Pathol 8: 5247-5251, 2015.

78. Zhang XQ, Tang R, Li L, Szucsik A, Javan H, Saegusa N, Spitzer KW and Selzman CH: Cardiomyocyte-specific p65 NF-kappaB deletion protects the injured heart by preservation of calcium handling. Am J Physiol Heart Circ Physiol 305: H1089-H1097, 2013.

79. Zeng M, Wei X, Wu Z, Li W, Li B, Zhen Y, Chen J, Wang P and Fei Y: NF- $\kappa$ B-mediated induction of autophagy in cardiac ischemia/reperfusion injury. Biochem Biophys Res Commun 436: 180-185, 2013.

80. Li J, Zhai Y, Ao L, Hui H, Fullerton DA, Dinarello CA and Meng X: Interleukin-37 suppresses the inflammatory response to protect cardiac function in old endotoxemic mice. Cytokine 95: 55-63, 2017.

81. Ding VA, Zhu Z, Xiao H, Wakefield MR, Bai Q and Fang Y: The role of IL-37 in cancer. Med Oncol 33: 68, 2016.

82. Abulkhir A, Samarani S, Amre D, Duval M, Haddad E, Sinnett D, Leclerc JM, Diorio C and Ahmad A: A protective role of IL-37 in cancer: A new hope for cancer patients. J Leukoc Biol 101: 395-406, 2017.

83. Moretta L, Pietra G, Montaldo E, Vacca P, Pende D, Falco M, Del Zotto G, Locatelli F, Moretta A and Mingari MC: Human NK cells: From surface receptors to the therapy of leukemias and solid tumors. Front Immunol 5: 87, 2014.

84. Kunz M and Ibrahim SM: Cytokines and cytokine profiles in human autoimmune diseases and animal models of autoimmunity. Mediators Inflamm 2009: 979258, 2009.

85. Semerano L, Assier E and Boissier MC: Anti-cytokine vaccination: A new biotherapy of autoimmunity? Autoimmun Rev 11: 785-786, 2012.

86. Taylor PC and Williams RO: Combination cytokine blockade: The way forward in therapy for rheumatoid arthritis? Arthritis Rheumatol 67: 14-16, 2015.

87. Striz I, Brabcova E, Kolesar L and Sekerkova A: Cytokine networking of innate immunity cells: A potential target of therapy. Clin Sci (Lond) 126: 593-612, 2014.

88. Gao W, Kumar S, Lotze MT, Hanning C, Robbins PD and Gambotto A: Innate immunity mediated by the cytokine IL-1 homologue 4 (IL-1H4/IL-1F7) induces IL-12-dependent adaptive and profound antitumor immunity. J Immunol 170: 107-113, 2003.

89. Yin D, Naji DH, Xia Y, Li S, Bai Y, Jiang G, Zhao Y, Wang X, Huang Y, Chen S, et al: Genomic Variant in IL-37 confers a significant risk of coronary artery disease. Scientific reports 7: 42175, 2017. 